\title{
圧延鋼板および熔接部つ機械的異方性についで
}

\author{
渡辺正紀** 出口義治**井上 清***
}

\section{On the Directionality of Mechanical Properties of Rolled Steels and Welded Parts**}

By M. Watanabe**, Y. Ideguchi** and K. Inoue**

\begin{abstract}
In the previous report ${ }^{1}$, we tried the tensile tests of the eleven kinds of killed steel plates in each of three directions, i.e. rolling-transverse-and thickness-direction and confirmed that tensile properties in the thickness direction are inferior to other two directions, especially in ductility.

In this paper, we studied the directionality of mechanical properties of mild steel and high tension steels. We also studied that of their heat-affected zones and deposited metals by submerged arc welding.

From these sxperiments, we knew that;

(1) Structural steels, containing high tension-steels, wich are rolled have little ductility in the thickness-direction and near that direction as shown in Figs. 4(a), 7(a), 7(b) and 8.

(2) Deposited metals by submerged arc welding have no mechanical directionality in tensile and bending propesties as shown in Figs. 3(a), 3(b), and 14.

(3) Heat-affected zones have the same mechanical directionality as the parent material.
\end{abstract}

\section{1. 序言}

近年鋲継手飞代って熔接継手が盛し飞採用されるように なってきたが，それにつれて鋼板はその板厚方问に加力さ れる機会が非常飞多くなってきた. そこて鋼板の板厚方向 の㙨械的性質も当然考虑されるべさであると思われる．從

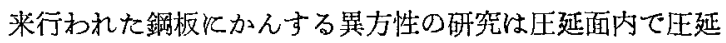
方向飞対する角度の相異飞よる機械的性質の差粠飞ついて のみであって板厚方向に対する資材は瓜上んど見当らない ようである.

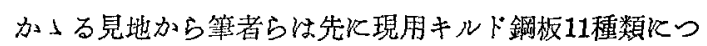
いて圧延方向, 去机值角方向, 未よび板厚方向の三方向 にかんし小型試験片を用いて引张試験を行い,引强强さは 三方向とも大差ないが板厚方向の正性は著しく不良で破断 あほとんど局部收縮なしに起ることを知っだ。

本論文は高张力銅について同様な゙実験を行った結果とキ ルド鋼板，熔着鋼ならびそ熱影響部について Fig. 3, Fig. 12 《一例を示すような各種方向の引張り，曲げ両特性を 詳細に調査した結果を取䌂めたものである。

\section{2. 試験裝置および試験片寸法}

引张試験に用いた試験機い非常に小型の試駼片を手軽に

* 原稿受付 昭和 30 年 7 月 21 日 (昭和 30 年度燃接学会登

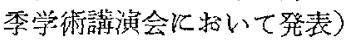

** 正是 大阪大学工学部 Member, Faculty of Engineering, Osaka University
使用できるいわゆるUniverso Meter と称せられるもので ある22。使用した試験片は

Fig. 1 飞示す形状寸法のむの である. 曲け試験は冶具を作 成して10瀬容量のアムスラー 型万能試験機を使用した. ま た曲げ試験は高温低温に括い

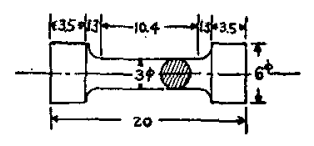

Fig. 1

Tensile specimen
ても行ったがとの治具, 恒温㯾, 試験片寸法は Fig. 2 飞示

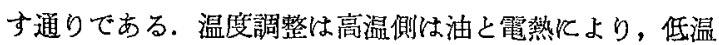
剆はドライアイスとアルコールを用いて行った。 。
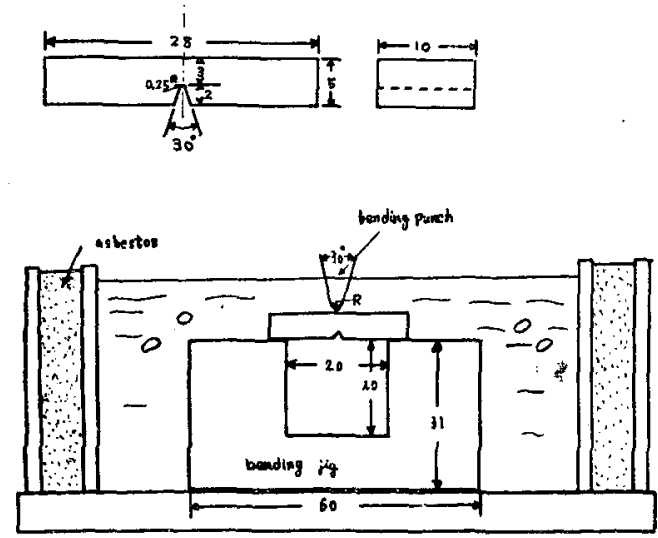

$\mathrm{R}$ : same size with the knife edge of charpy tester

Fig. 2 Bending specimen and apparatus for bending test 


\section{3. 突験詳細}

$3 \cdot 1$ 実験 (1) 軟鋼板の異方性

a ）引張特性

試験材料は現用キルド鋼板（板厚. $28 \mathrm{~mm}$ ) で Sulphur Printをとったが硫黄の偏析は見られなかった. 試騟片は Fig. 3 に示すように各面 $22.5^{\circ}$ つうつ゚らした 12 万向より採 取した. 実験結果を図示するとFig. 4 (a), Fig. 4 (b) のよ うになる. 半径方向を引張強さ, 破断応力, 伸率, 断面収

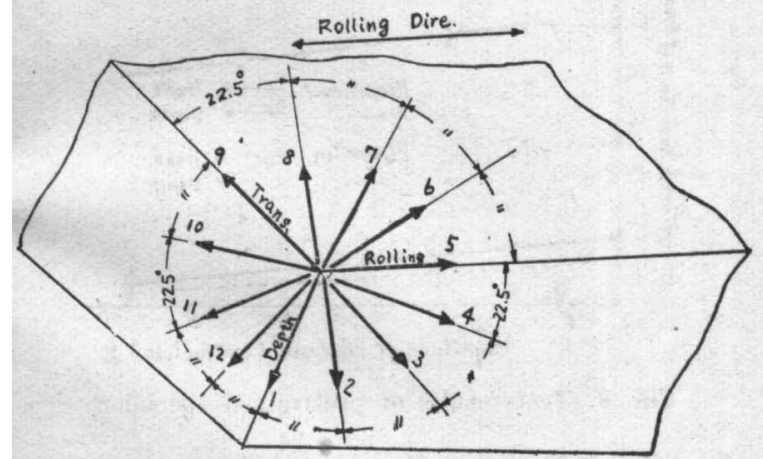

Fig._3】 Tested_direction ${ }_{\alpha}$ in tension

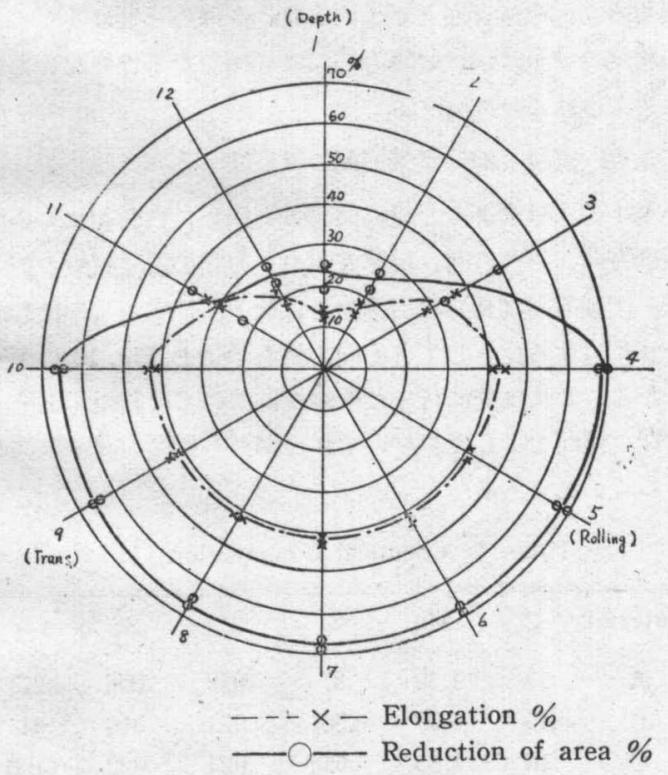

Fig. 4 (a) Test result
縮率をとり半徍上の数字は Fig. 3 K示した試験方向を示 すむので，1，5，9：とれぞれ板厚方向，圧延方向，直角方 向に当る. 破断状况の写真を正Fig. 5 飞示した. 各方向と も強度の点より見れば大差ないが歪性は 4,10 , 方向から厚 さ方向に近つくにうれ急激に減少し破断の外钼写真は，こ れらの延性の劣る方向では圧延面に平行な面に沿って脆く 破断していることを明瞭に示している.

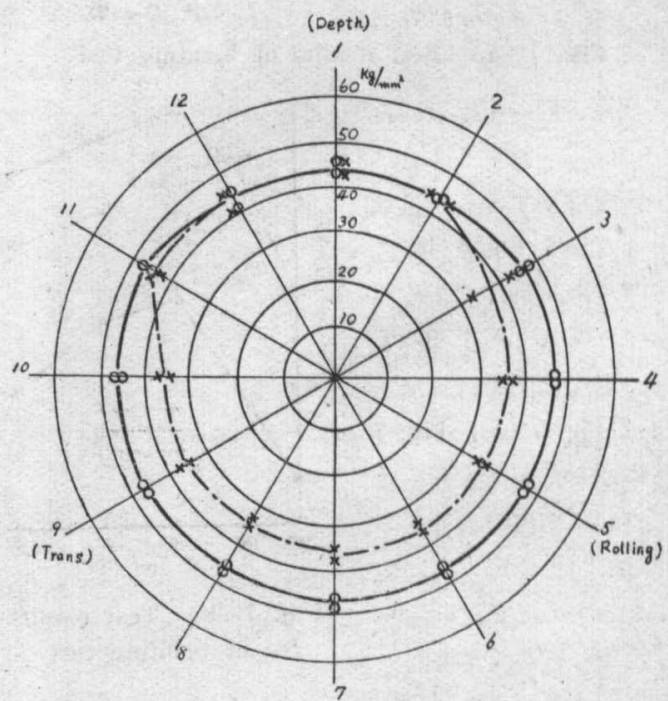

$$
\begin{array}{ll}
--x-\text { Breaking stress } \\
-0-\text { Ultimate strength }
\end{array}
$$$$
\text { Fig. } 4 \text { (b) Test result }
$$

b) 曲げ特性:

曲け試験片の採取方向としては Fig. 6 (a) 飞示す. 6 方 向が考えられるが $\mathrm{D}_{1}$ と $\mathrm{D}_{2}, \mathrm{~T}_{2}$ と $\mathrm{R}_{2}, \mathrm{R}_{1}$ と $\mathrm{T}_{2}$ はそれぞ れ大差ないものと考えられる ${ }^{3}$ ので筆者らは切欠の長手方

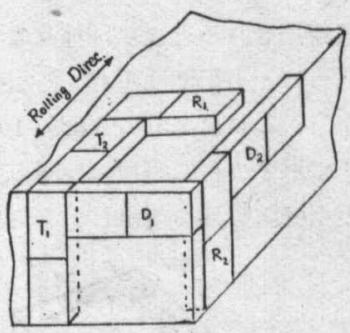

(a)

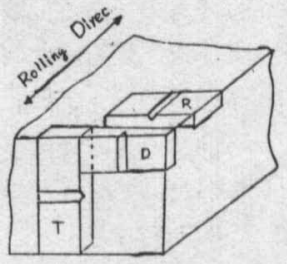

(b)
Fig. 6 Tested direction of bending test

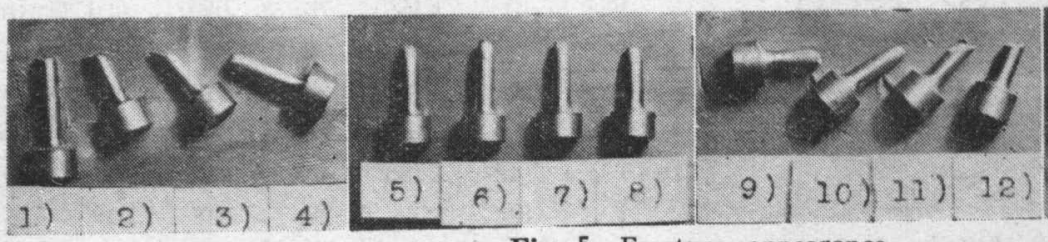

Fig. 5 Fracture appearance

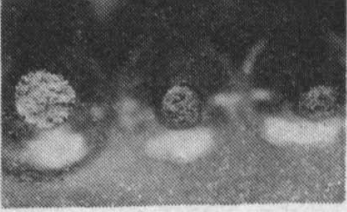

Depth. Roll. Trans.

1)

5)

9) 


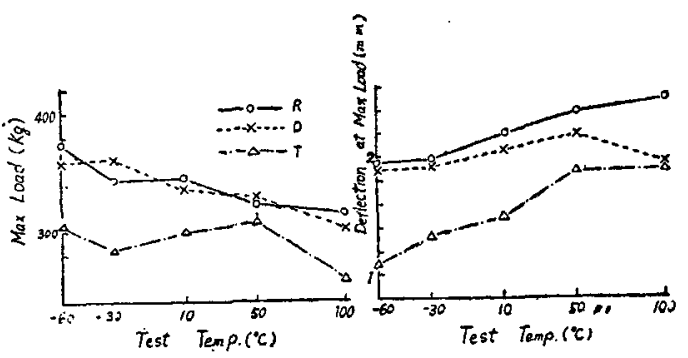

Fig. $\eta$ (a) Test results of bending test

向が圧延方向，板厚方向， 街方方向に一致するような 試験片を採用することにし た，すなわち Fig. 6 (b) 飞 示すような試験片である。 試駼は $-60^{\circ} \mathrm{C}$ 加 $100^{\circ} \mathrm{C}$ までの湿度笵国で行った。 結累致 Fig. 7 (a), Fig. 7 （b）に示したが最大荷重は 板厚方向に切欠のあるもの ( D試験片)上卧延方向火切 欠のあるもの ( $\mathrm{R}$ 試験片)

とは大望ないが直角方向に

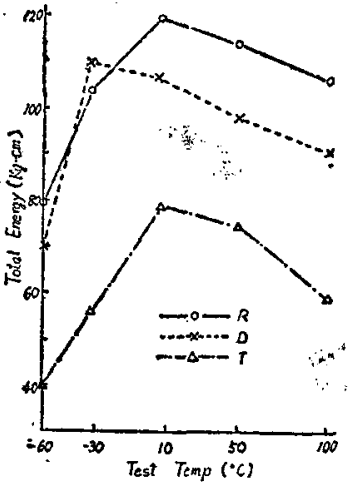

Fig. 7 (b) Test results of bending test
切久のあるもの（T試験片）はかない小さい。これはどの 温度でも同じ傾何を示すようてあるままた最大荷重持の変 形舉や吸陨エホルギ一も同じような傾向を示しているが，

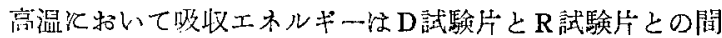

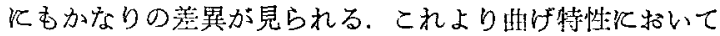
む非延鋼板は方向性を示し特に板厚方向に採取された試験 片は強度，延性とも劣るようである。

c）常温予歪を受けた軟鋼板の引張特性

鋼板は榡造物の一部として使用されるときには種々の加 工を受けるものである，笋者らは正方形断面を有寸る引舀 試験片 3 本を压延方向飞切出し，これ飞 2.5\%，5.8\%，10.9

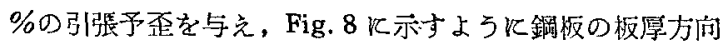

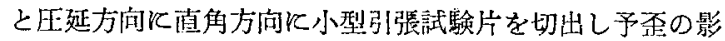

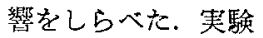
結果を図示すると Fig.9のようになる.

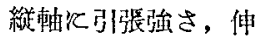
率, 断面収縮率を り横制柢厚力向， 直角方向心受汁た予 歪量をとったもので ある.圈よりわかる ように二方向とも引 㜊强さ予企の増加

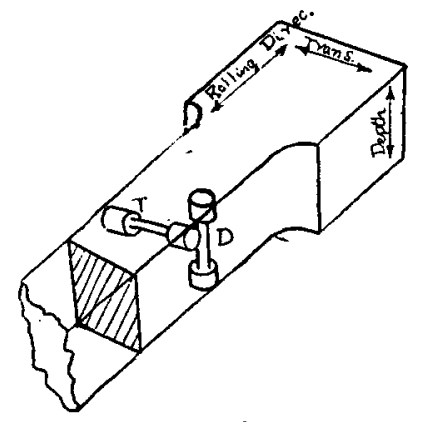

Fig. 8
Pre-strained specimen
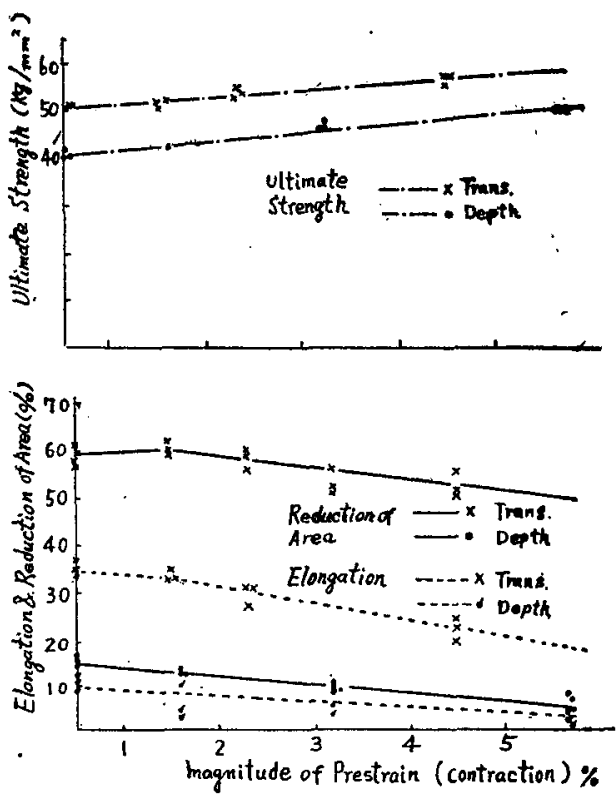

Fig. 9 Test results of prestrained specimen

とともに增大寸るが伸率, 断面収縮率は逆に減少している。 しかもその変化罩は雨方向ともはとんど等しい。これより

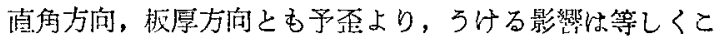

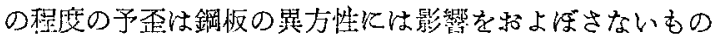
と考觉られる.

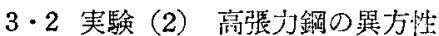

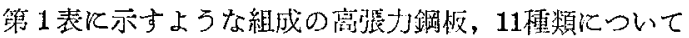
正延方向，直角方向，板厚方向の三方面の引热試験を行。

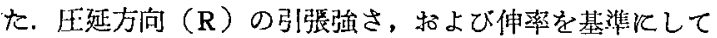
それに対する比として各方向の值を示すと Fig. 10 のう になる.これは先に行った軟鎆板についての結果〉 と全く 同様な傾问を示して拾りいずれの鋼板も板厚方向の延性が 著しく不良である.

Table 1 Chemical Composition (\%)

\begin{tabular}{c|c|c|c|c|c|c}
\hline \hline Material & $\mathrm{C}$ & $\mathrm{Mn}$ & $\mathrm{Si}$ & $\mathrm{P}$ & $\mathrm{S}$ & $\mathrm{Cu}$ \\
\hline $\mathrm{A}$ & .17 & 1.30 & .37 & .019 & .008 & .27 \\
$\mathrm{~B}$ & .15 & 1.60 & .58 & .021 & .010 & .31 \\
$\mathrm{C}$ & .18 & 1.55 & .514 & .024 & .022 & .195 \\
$\mathrm{D}$ & .18 & 1.54 & .497 & .022 & .022 & .197 \\
$\mathrm{E}$ & .12 & 1.15 & .705 & .020 & .020 & .183 \\
$\mathrm{~F}$ & .19 & 1.344 & .223 & .018 & .009 & .164 \\
$\mathrm{G}$ & .195 & 1.377 & .229 & .017 & .006 & .152 \\
$\mathrm{H}$ & .130 & 1.19 & .481 & .021 & .006 & .176 \\
$\mathrm{I}$ & .142 & 1.183 & .475 & .013 & .007 & .192 \\
$\mathrm{~J}$ & .19 & 1.32 & .28 & .018 & .018 & .15 \\
$\mathrm{~K}$ & .19 & 1.30 & .61 & .018 & .013 & .15 \\
\hline
\end{tabular}




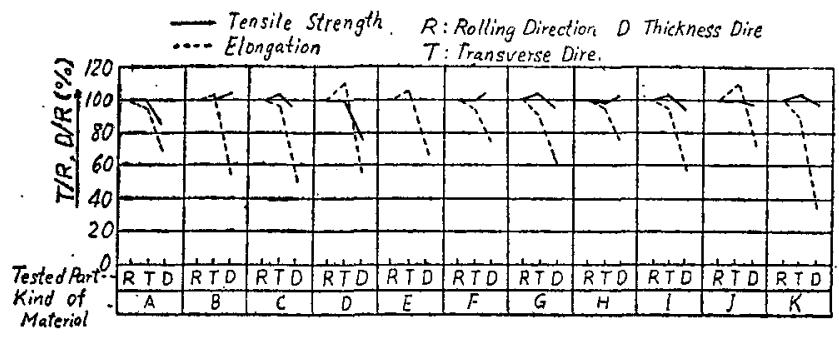

Fig. 10 Experimental results

起すことなく擬く破断す るもので，このような観点 から実験に微少な切欠があ る場合汇その切欠㹸対し種 々な角度から引纬るとき， どのよらな現象が見られる 加次のような奏験を行って みた。

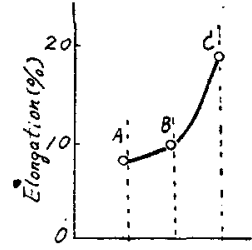

Fig. 12 Test result

試験片として Fig. 11 亿示すような, 軸方向飞

$3 \cdot 3$ 考察

以上の実験結果より任延操作をうけた鋼板はすべて，板 㞓方向ないしそれに近い方向では非常に延性が劣西々いい 得るようであるが，この板厚方向の延性の不足について考 察を加えて見る.

從来原延方向と直角方向との機械的性質の相異すなわ方 異方性については繊維状組織や MnSの分们状態などがそ の原因として諭ぜられている4がこれらの方向の機械的性 質の相異岋引张試験に括ける引張強さや伸率などの数值的 な差買が䦌題とされているもので，两方向とも十行な局部 収縮を起しており破断の特性としては何ら異なるとこるは ないしかるに笺者らの行った実験では压延面に平行な平 面内で各方向に切出された試験片はいずれも，断面も良く 収縮し十分な延性を示しているが板厚方向执よびこれね近 い方向ではどの角度のものであ圧延面と平行な面汾って

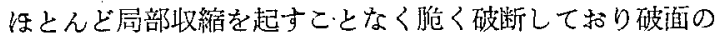
ようすむ他の二方向のものと異なっている.（Fig. 5 参照） このような現象は從来の説明では充分説明することはでき ないよう飞思わ扎る.これについて筆者らは次のように考 える，すなわち正延銅板では鋼塊より王延されるにつれて 各種の介在物は扁平になり压延面飞平行飞並ぶことが予想 される.そしてこれら層をなしたものの中で比較的㬶い介 在物は応力を弓けるとき《沏欠として作用するものと考 えられる、したがって板厚方向挌よびそれに近い方向に引 张られる場合，切欠効果が最も強く現われるので局部収縮
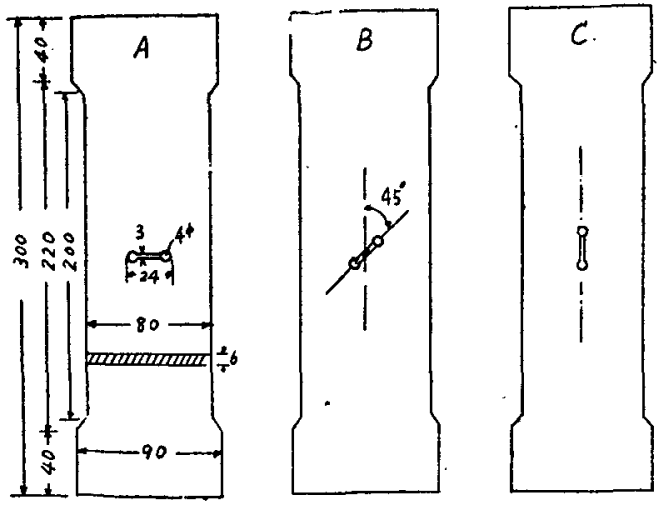

Fig. 11 Tensile slit specimen $90^{\circ} ４ 5^{\circ} ， 0^{\circ}$ の角度をもつストリッを入れたるのを用いス リットを挾さ標点距離 $140 \mathrm{~mm} の$ 伸びを测定した，この結 果は Fig. 12 のように引張方向にスリットが傾いた程伸び は小さくなっている．すなわり力の墈く方向に対し直角方 向化方る切欠は平行方向化あるものより鋭くき」このため 伸びが少く脆く破断する傾向火あることが知られる。これ は鋼板の厚さ方向に切出された試験片と同じ傾向を示して いるようで，上述した板厚方向の延性の不足に対する筆者 らの推察を正当化するものである.

\section{$3 \cdot 4$ 実験（3）熔着金属の異方性}

熔着金属の機械的性質の異方性てかえしては大型の多層 盛熔着金属を用いて行った大西影氏5の研究がある.この 中で大西氏は多尿盛の場合各征間汇微細な気泡が存在して いてこれがため異方性が見られると結諭して招られる、し かし単㲊熔着鋼にたいするこの種の試験は非常に小型の試 験片を使用する必要があるので事実上困覲でこれにかんす る研究はほとんど見当らない。

箞者らは小型試験片を用いて，ユニオンメルトによりつ くられた算畨, 多厤盛りの, 今日広く実用されている熔接 継手の熔着鋼飞ついて機械的性質の異方性を調查した。

(A) 単層熔着鋼

a) 引嬁特性

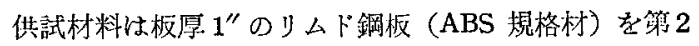
表に示す条件により熔接して作成した熔着鋼である。焀着 金属中央縦断面の macro etch 写真を Fig. 13 亿示したが 柱状晶はほとんど直線上に售接進行方向と $65^{\circ}$ 〜 $70^{\circ}$ の倾斜 をむって発達している. 試験片は Fig. 14 K示すように16 方向より採取した． $10^{\prime} ， 11^{\prime}, 12^{\prime}, 2^{\prime}$ は図からわかるよう 飞 10，11，12，2がれぞれ，らようどその面での柱状昆の

Table 2 Welding Condition

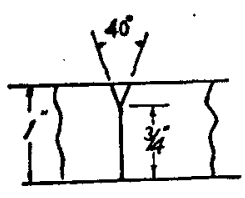

\begin{tabular}{|c|c|c|c|c|c|}
\hline Puss & $\begin{array}{l}\text { Compent } \\
(A) \text { (1) }\end{array}$ & $\begin{array}{l}\text { volt } \\
\text { (v) }\end{array}$ & $\begin{array}{l}\text { Speed } \\
\text { (cminin) }\end{array}$ & Flox & filler rod \\
\hline B.P. & 720 & 30 & 38 & $68020 D$ & Linde $" 36 \%$ \\
\hline F.P. & 1000 & 32 & 24 & - & 。 \\
\hline
\end{tabular}

Groove Detail 


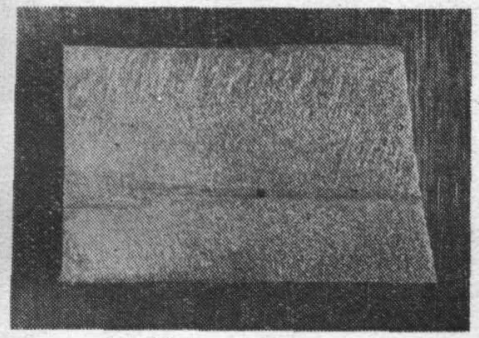

Weld Direc, $\rightarrow$

Fig. 13 Macro etch Phot. of deposited metal at center-section

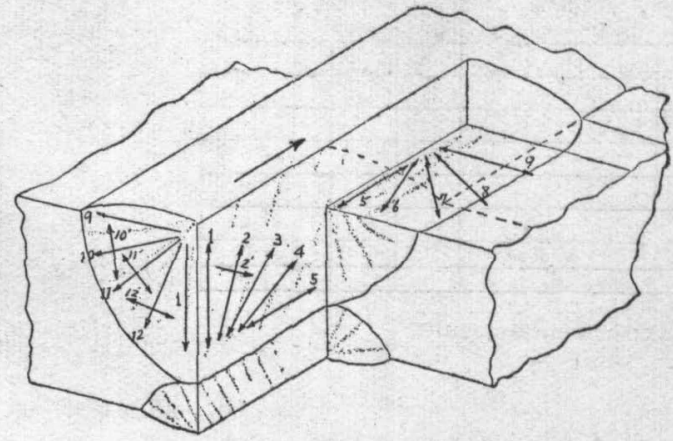

Fig. 14 Tested direction in tension test

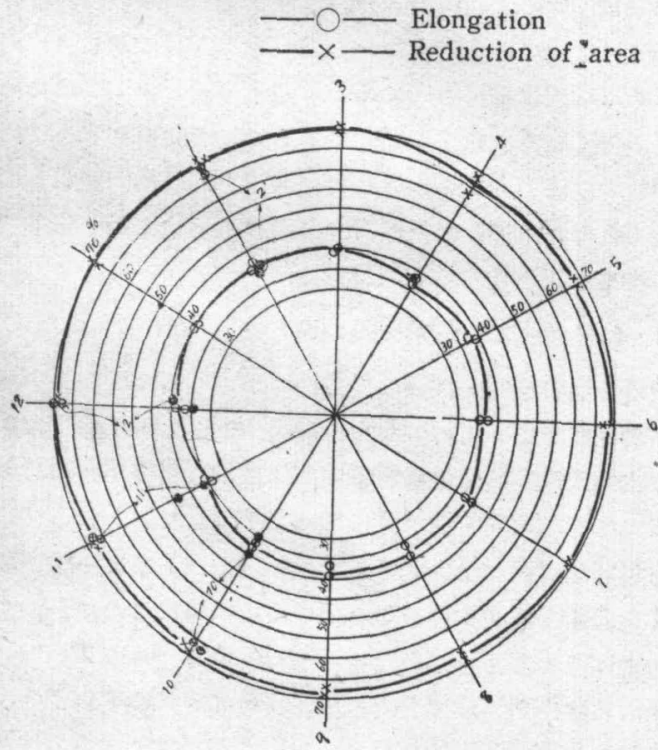

Fig. 15 (a) Test result

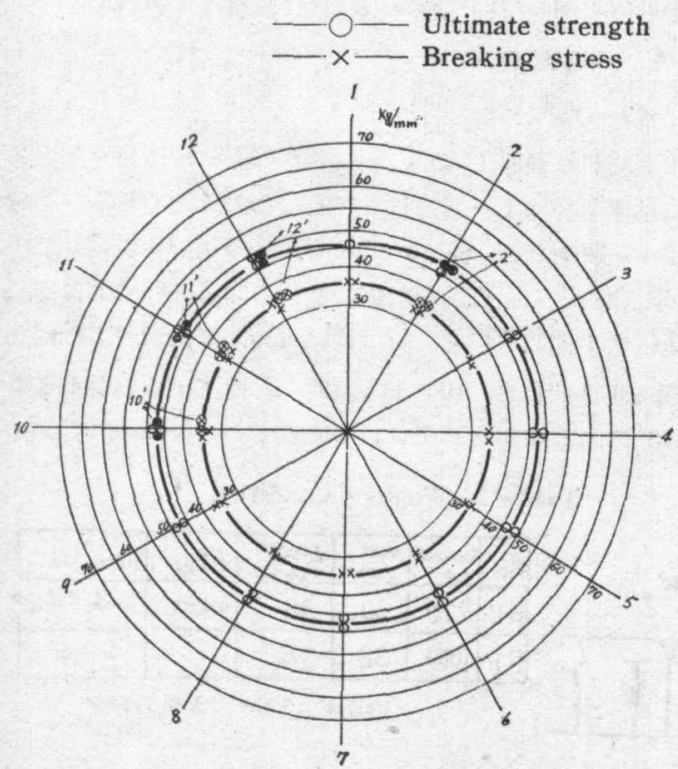

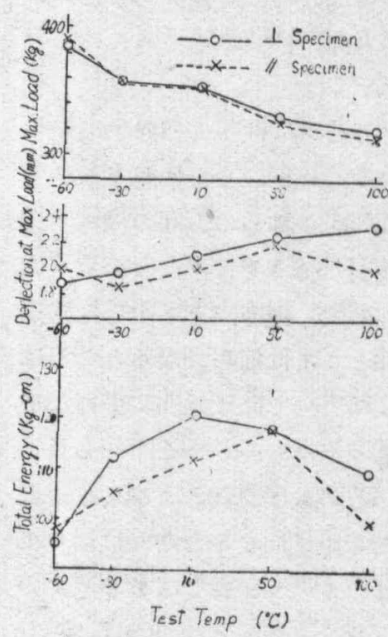

Fig. 16

Test result of bending test

方向に近いのでそれと直 角にえらんだものである

Fig. 1 (a) 15 (b) 飞実 験結果を示した. 図中柱 状晶に直角なるのについ ての結果は番号にダッン ュをつけてある.これら の結果からわかるように 伸率, 断面収縮率, 引張 强さ, 破断応力などいず れの方向に沶いてすほと えど同じ值で，方向によ る差は認められない,す なわちユニオンメルトに よる一層熔着鋼は引張特 性においては全く方向性 はないと考え得る.

b) 曲げ特性 引㖘りの場合と同じ材 料より柱状晶の方向に切 欠のあるものと垂直方向 に切欠のあるものを熔着 鋼の中央部から採取し, $-60^{\circ} \mathrm{C} \sim 100^{\circ} \mathrm{C}$ のつの 温度において曲げ試験を 行いFig. 16 と示す結果 を得た.これより曲げ特 性飞招いてもほとえど方向性はないといい得るようであ る.

\section{（B）多層盛熔着鋼}

ユニオンメルトより Table 3 に示す条件で, 単層盛の場 合と同じ要領でつくられた継手の熔着部より Fig. 17 そ示 すような層間を含んだ深さ方向（D試験片）と横方向（T 試験片）について引張特性を調查した. 結果は第 4 表に示 すと括りで引張強さ，伸率，断面収縮率などほとんど差異 は認められないようである. な捻のため層間を検鏡した が気泡は見当らなかった。

Table 3 Welding Condition

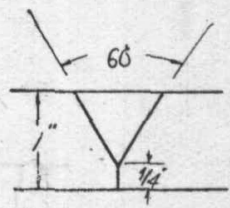

groove Detail

\begin{tabular}{|c|c|c|c|c|c|}
\hline Poss & $\mid \begin{array}{c}\text { Gument } \\
\text { (A) }\end{array}$ & $\begin{array}{l}\text { Vott } \\
\text { ovi }\end{array}$ & 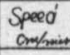 & Flenx & $\begin{array}{l}\text { filler } \\
\text { fod }\end{array}$ \\
\hline B.P. & 480 & 30 & 38 & 500.200 & $01666249033 / 1 / 6$ \\
\hline 1. $P$ & 750 & 30. & 30 & " & " \\
\hline 2.P. & 660 & 31 & 24 & . & . \\
\hline $3 P$ & 660 & 32 & 24 & . & . \\
\hline
\end{tabular}

Welden; Sw-za Type 
$3 \cdot 5$ 実験（4） 母材熱影響部の異方性

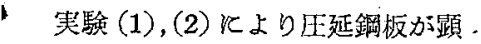
著な機械的方向性を示すことを知り ，また実験 (3) 飞扣いて熔着金属火 注異方性の存在しないことを確認し た. そこでその中間存在する母材

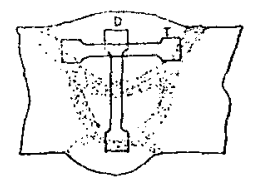

Fig. 17 の熱影響部とついて実験を行った. Detail of test part 試験片は板原方向と熔接方向より採取した。. 結果は Fig.18 に示すようにやはり板厚方向は惩性が非常飞劣り母材原質 部々同㥞な傾向を示している。これより熔接第化よって組

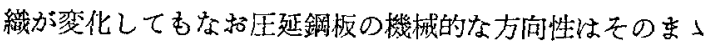
のこることが知られる。

Table 4 Test Result

\begin{tabular}{|c|c|c|c|c|}
\hline $\begin{array}{l}\text { Tested } \\
\text { Direction }\end{array}$ & 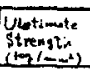 & $\begin{array}{l}\text { Boting } \\
\text { Stress } \\
(k, \leqslant=2)\end{array}$ & $\begin{array}{c}\text { Red. of Area } \\
(\%,)^{2}\end{array}$ & $\begin{array}{l}\text { Flongetion } \\
\text { (re) }\end{array}$ \\
\hline$T$ & 53.0 & 40.6 & 52.8 & 36 \\
\hline$D$ & 51.1 & 40.6 & 53.3 & 33 \\
\hline
\end{tabular}

\section{4. 結 語}

小型試験片を用いて区延鋼板，熔着銅，母材熱影響部の 方向による引张特性挌よび曲げ特性の差異を調查したが要 約すると次の通りである.

1. いかなる化学組成の棈造用鋼材季圧延操作を受ける

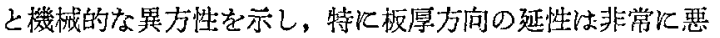
くなる.これの原因としては目下考究中で直ちに明言する ことはできないが，压延炕よって死延面に沿って平行並 び，扁平になった各種の介在物がこれ和直角に力がか」る 際化鋭い切欠の上うな作用を呈して，これがため陒く破 断し延性が劣ると考兄られる.

2. 現在構造物の熔接継手飞盛ん飞使用されているュニ オンタルトによる熔着金属は柱状晶の方向に関係なく，引
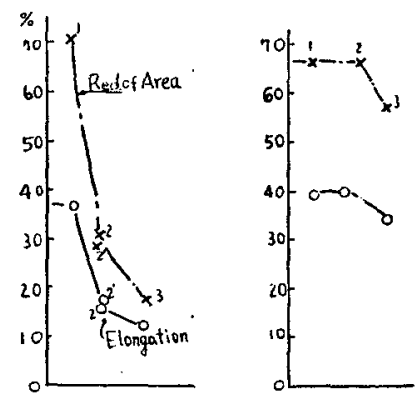

張り，曲け㳢特性之 も方向性なく機械的 特性上からは全く等 方性と見做しろる。

3. 母材熱影響部 愹接熱により，改 缮されることなく原 質部之同程度の方向 性をのこしている。

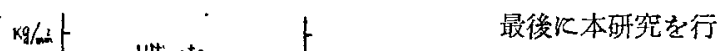
う火際し一部試片の 作製便宜を与えら れた大阪変王器研究 部の木谷聰生氏なら び飞実験実施に

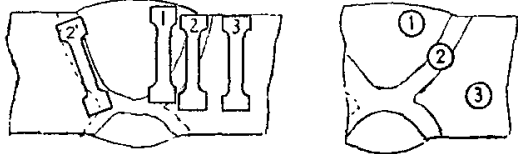

Fig. 18 Experimental result 当って協力下き った本学大学院 山口常炤君飞た いし深く感謝の 意を表する.

\section{辁}

1）渡辺，出口，臼杵；村料試験 第 4 巻第 19 号（昭和 29年春講演)，昭和 29 年秋，仲教授の熔接学会講演が ある。

2）註1)の論文中に詳細述へている.

3) Wilber M. Willson. Weld. JI. April 1948

4）例总ば 内山道良 鉄と鋼 第35年 2 号（昭和 24 年）

“第36年 1 号（昭和25年）

" 第37年 4 号（昭和26年）

5) 大西慜 熔接学会誌 第11巻 第 2 号 (昭和16年)

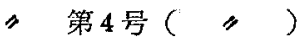

" 第 6 号 (" )

\section{お 知 ら 世}

本月をもつて本会会計年度が変ります

現在会費未納の会員は至急納入下さいます

樣御願致します

昭和 31 年 2 月 